\title{
ANALISIS RISIKO KESELAMATAN KERJA PADA PROYEKPENGEMBANGAN BANDARA INTERNASIONAL JUANDA TERMINAL 2 SURABAYA
}

\author{
Occupational Safety Risk Assessment at Development Project of Terminal 2 Juanda \\ International Airport Surabaya
}

\author{
Reny Indrayani \\ FKM Universitas Jember.Jalan Kalimantan 37, Jember 68121. \\ Email :renyindrayani.fkm@unej.ac.id
}

\begin{abstract}
The construction sector played an important role in development and was the biggest contributor of work accident rate in Indonesia. The aim of the research were to analyze human, methods, machines, materials, and environment element as cause of occupational accidents. This was a cross-sectional observational research conducted in October 2012 to March 2013. This research was carried out with several integrates stages which include risk identification, risk assessment and priorities formulation, root cause analysis, and ended by recommendations for controlling risk and hazard. Risk identificationshowed that there were 100 risks that couldthreaten the workers. The following categories were: 4\% low risk categories, 48\% moderate risk, 39\% high risk, and 9\% extreme risk. Through the $Q$ sort technique obtained five priority safety issues: workers falling from height, electric shock, workers stung by material lifted, fires or explosions, and the scaffolding collapsed. Based on root cause analysis, it showed that the most likely root cause of the problems was dominated by the human factor such as: fatigue due to overtime work, lack of experience and understanding of the procedure, lack of awareness of the importance of the ocupational safety and health.
\end{abstract}

Keywords:construstion, risk assessment, root cause.

\begin{abstract}
Abstrak
Sektor konstruksi memegang peranan penting dalam pembangunan dan merupakan penyumbang angka kecelakaan kerja tertinggi di Indonesia.Penelitian ini bertujuan untuk menganalisis unsur manusia, metode, mesin, material, dan lingkungan sebagai penyebab kecelakaan kerja.Penelitian ini merupakan penelitian observasional dengan rancang bangun cross-sectional yang dilaksanakan pada Oktober 2012-Maret 2013. Penelitian ini dilaksanakan dengan beberapa tahap yang meliputi identifikasi risiko, penilaian dan penyusunan prioritas risiko, root cause analysis dari prioritas risiko, dan perumusan rekomendasi pengendalian risiko dan hazard. Merujuk pada hasil identifikasi risiko diketahui terdapat 100 bahaya yang dapat mengancam keselamatan pekerja dengan kategori: 4\% low risk, 48\% moderate risk, 39 high risk, dan 9\% extreme risk. Melalui $Q$ sort technique diperoleh 5 prioritas masalah: pekerja jatuh dari ketinggian, pekerja tersengat aliran listrik, pekerja tertimpa material yang diangkat, kebakaran atau ledakan, dan perancah roboh.Berdasarkan root cause analysis, diketahui bahwa penyebab dasar yang dominan adalah dari faktor manusia yakni: kelelahan kerja akibat lembur, pekerja kurang Reny Indrayani adalah Bagian Kesehatan dan Keselamatan Kerja Fakultas Kesehatan Masyarakat Universitas Jember
\end{abstract}


pengalaman dan kurang pemahaman terhadap prosedur kerja, serta kurangnya kesadaran pekerja tentang K3.

Kata kunci: konstruksi, analisis risiko, penyebab dasar.

\section{PENDAHULUAN}

Sektor konstruksi memegang peranan penting dalam pembangunan.Peranan sektor konstruksi dalam pembangunan diwujudkan dengan pengadaan atau pendirian sarana dan prasarana yang berfungsi mendukung tumbuh kembang berbagai bidang terutama bidang ekonomi, sosial, budaya, dan transportasi, tetapi juga dapat menimbulkan berbagai dampak yang tidak diinginkan salah satunya yang menyangkut aspek keselamatan kerja.Menteri Tenaga Kerja dan Transmigrasi menyatakan bahwa sektor konstruksi merupakan penyumbang angka kecelakaan tertinggi ${ }^{1}$. Berdasarkan data Jamsostek, dari total jumlah kasus kecelakaan kerja yang terjadi di Indonesia yakni sebesar 99.491 kasus pada tahun 2011, hampir 32\% atau sekitar 31.837 kasus terjadi di sektor konstruksi yang meliputi semua jenis pekerjaan proyek gedung, jalan, jembatan, terowongan, irigasi bendungan dan sejenisnya ${ }^{6}$.

Mengantisipasi hal ini, pemerintah telah mencanangkan upaya peningkatan keselamatan dan kesehatan kerja dengan mewajibkan penerapan SMK3 termasuk di bidang konstruksi. Ramli (2010) menyatakan bahwa inti SMK3 adalah Manajemen Risiko yang tujuan utamanya adalah mengelola risiko untuk mencegah terjadinya kecelakaan atau kejadian yang tidak diinginkan melalui proses identifikasi bahaya, penilaian risiko, dan pengendaliannya ${ }^{2}$. Ketepatan dalam menerapkan proses manajemen risiko keselamatan kerja utamanya dalam tahap pengendalian risiko dalam suatu proyek konstruksi adalah kunci keberhasilan dalam pengelolaan risiko. Pengendalian risiko terhadap unsur manusia, metode, mesin, material, dan lingkungan di bidang konstruksi ini diharapkan dapat memperkecil risiko sehingga menekan angka kejadian kecelakaan kerja.

Saat ini PT. Angkasa Pura tengah melakukan pengembangan terhadap Bandara Juanda Surabaya dengan membangun terminal baru untuk penerbangan internasional.Bandara ini, didirikan di atas lahan seluas 32.000 meter persegi. Pembangunan fisik Bandara Internasional Juanda Terminal 2 yang menelan anggaran sebesar 380 miliar rupiah ini dikerjakan oleh kontraktor utama PT X. Terminal tersebut dirancang dengan kapasitas 4 4,5 juta penumpang per tahun. Pendirian bangunan besar ini ditargetkan selesai dalam waktu 11 bulan. Waktu 11 bulan untuk bangunan seluas ini merupakan jangka waktu yang relatif singkat sehingga untuk mengejar target atau batas waktu tersebut proyek ini memerlukan penggunaan teknologi tinggi dan harus melibatkan banyak pekerja. Penggunaan teknologi tinggi yang dapat menjadi sumber hazard dan keterlibatan banyak pekerja dalam suatu proyek konstruksi tentu akan meningkatkan risiko kecelakaan kerja. Terbukti dari data insiden pada bangunan dengan karakteristik serupa (bangunan horizontal) yakni GOR Boker Ciracas yang dibangun oleh kontraktor PT. X, dimana dalam rentang waktu Januari 2008 sampai dengan januari 
2009 tercatat terjadi 29 kasus kecelakaan, sementara data insiden Proyek Pengembangan Bandara Internasional Juanda Terminal 2 sendiri menunjukkan bahwa telah terjadi sebanyak 15 kasus kecelakaan selama kurun waktu 2 bulan yakni Oktober sampai dengan November 2012 (Data Primer K3LMP PT. Waskita, 2012). Tujuan penelitian ini ialah menganalisis risiko kecelakaan kerja serta merumuskan rekomendasi untuk Proyek Pengembangan Bandara Internasional Juanda Terminal 2 Surabaya melalui kajian manajemen risiko keselamatan kerja.

\section{METODE}

Penelitian ini adalah penelitian deskriptif dengan pendekatan kualitatif dimana objek penelitiannya terdiri dari pelaku, tempat, dan aktivitas. Pelaku atau responden pada penelitian ini antara lain: koordinator (senior) K3LMP, koordinator struktur, koordinator arsitektur,mandor, serta perwakilan pekerja lapangan (buruh bangunan) sejumlah 6 orang. Tempat penelitian adalah seluruh lingkungan yang menjadi wilayah pembangunan pada Proyek Pengembangan Bandara Internasional Juanda Terminal 2 Surabaya, dan aktivitas yang menjadi objek pengamatan dalam penelitian ini adalah seluruh kegiatan atau aktivitas konstruksi yang dilakukan pada Proyek Pengembangan Bandara Internasional Juanda Terminal 2 Surabaya.Teknik pengumpulan data yang digunakan yaitu observasi langsung ke lingkungan kerja proyek, kajian dokumentasi terhadap dokumen terkait, dan wawancara sertabrainstorming techniquedengan responden penelitian.Penelitian ini dilaksanakan pada Oktober 2012 sampai dengan Maret 2013.

\section{HASIL PENELITIAN DAN PEMBAHASAN}

\section{Identifikasi Risiko}

Hasil identifikasi risiko keselamatan kerja yang telah dilakukan peneliti melalui tiga metode yakni observasi langsung ke lingkungan kerja proyek, kajian dokumentasi terhadap dokumen terkait, dan brainstorming technique dengan responden dapat dilihat pada tabel

1.

Tabel 1 Hasil Identifikasi Risiko Keselamatan Kerja pada Proyek Pembangunan Bandara Juanda Terminal 2 Surabaya Tahun 2013

\begin{tabular}{cll}
\hline No & \multicolumn{1}{c}{ Aktivitas } & \multicolumn{1}{c}{ Deskripsi Risiko Keselamatan Kerja } \\
\hline 1 & Pembersihan Lokasi & $\begin{array}{l}\text { Pekerja tergores atau terpotong material tajam } \\
\text { Pekerja tersandung, jatuh dari ketinggian yang sama } \\
\end{array}$ \\
& & Pekerja tergigit ular \\
\hline 2 & Mobilisasi dan & Pekerja tertabrak alat berat \\
& demobilisasi alat berat & Pekerja terpapar debu \\
& & Material atau alat lain tertabrak alat berat \\
\hline 3 & Pembongkaran Bangunan & Pekerja tertimpa bongkaran bangunan \\
& existing & Pekerja tergores atau Tersayat material tajam \\
& & Mata Pekerja Terkena serpihan material \\
& & Pekerja tertabrak lengan excavator \\
\hline 4 & Penggalian tanah dan & Pekerja terkena pacul atau alat gali lainnya \\
\hline
\end{tabular}




\begin{tabular}{|c|c|c|}
\hline No & Aktivitas & Deskripsi Risiko Keselamatan Kerja \\
\hline & perapihan dasar galian & $\begin{array}{l}\text { Pekerja terpeleset atau terjatuh } \\
\text { Pekerja terkena longsoran galian }\end{array}$ \\
\hline 5 & $\begin{array}{l}\text { Pasang bongkar } \\
\text { scaffolding }\end{array}$ & $\begin{array}{l}\text { Scaffolding roboh } \\
\text { Pekerja jatuh dari ketinggian (di atas } 2 \text { meter) }\end{array}$ \\
\hline 6 & $\begin{array}{l}\text { Pengoperasian dan } \\
\text { angkat angkut material } \\
\text { menggunakan Tower } \\
\text { Crane }\end{array}$ & $\begin{array}{l}\text { Pekerja tertimpa material yang diangkat } \\
\text { Pekerja tertabrak material yang diangkat } \\
\text { Kerusakan material yg terjatuh atau tertimpa } \\
\text { TowerCrane roboh } \\
\text { Operator terjatuh saat memanjat tower crane }\end{array}$ \\
\hline 7 & $\begin{array}{l}\text { Welding, Cutting (Hot } \\
\text { work) }\end{array}$ & $\begin{array}{l}\text { Mata Pekerja Terkena serpihan material (gram) } \\
\text { Kulit pekerja terkena percikan api las } \\
\text { Iritasi Mata terpapar fume logam atau asap las } \\
\text { Pekerja tersengat arus listrik (las elektroda) } \\
\text { Hubungan arus pendek atau Konsleting (kabel power) } \\
\text { Pekerja terkena ledakan tabung LPG (las LPG) } \\
\text { Kebakaran akibat percikan api }\end{array}$ \\
\hline 8 & $\begin{array}{l}\text { Grinding, Chipping, } \\
\text { Cutting }\end{array}$ & $\begin{array}{l}\text { Mata Pekerja Terkena serpihan material } \\
\text { Pekerja tersayat atau terpotong alat kerja }\end{array}$ \\
\hline 9 & Pemancangan & $\begin{array}{l}\text { Pekerja tertimpa tiang pancang yang roboh } \\
\text { Pekerja Tertabrak tiang pancang } \\
\text { Pekerja terluka oleh alat kerja (linggis pendek } \\
\text { dan/atau bodem) } \\
\text { Pekerja tergores logam sambungan }\end{array}$ \\
\hline 10 & Pembuatan Lean concrete & $\begin{array}{l}\text { Iritasi kulit terkena percikan semen } \\
\text { Mata pekerja terkena percikan semen }\end{array}$ \\
\hline 11 & $\begin{array}{l}\text { Pekerjaan bongkar } \\
\text { pasang bekisting }\end{array}$ & $\begin{array}{l}\text { Pekerja tergores material bekisting (kayu atau logam) } \\
\text { Pekerja tertusuk paku } \\
\text { Pekerja terpukul palu }\end{array}$ \\
\hline 12 & Pekerjaan pembesian & $\begin{array}{l}\text { Pekerja tersayat besi } \\
\text { Pekerja tertusuk besi bendrat } \\
\text { Pekerja terjepit mesin bending } \\
\text { Pekerja terjepit alat kerja (tang) atau terjepit besi }\end{array}$ \\
\hline 13 & $\begin{array}{l}\text { Pekerjaan pengecoran } \\
\text { (lantai dasar dan slofe) }\end{array}$ & $\begin{array}{l}\text { Iritasi kulit terkena percikan semen } \\
\text { Mata pekerja terkena percikan beton } \\
\text { Pekerja terpapar getaran vibrator }\end{array}$ \\
\hline 14 & $\begin{array}{l}\text { Pekerjaan bongkar } \\
\text { pasang bekisting di } \\
\text { ketinggian }\end{array}$ & $\begin{array}{l}\text { Pekerja tergores material bekisting (kayu atau logam) } \\
\text { Pekerja tertusuk paku } \\
\text { Pekerja terpukul palu } \\
\text { Pekerja terjatuh dari ketinggian } \\
\text { Pekerja kekurangan oksigen (bekisting GWT) }\end{array}$ \\
\hline 15 & Pemasangan steeldeck & $\begin{array}{l}\text { Tergores material besi } \\
\text { Terjepit material besi } \\
\text { Tersengat arus listrik }\end{array}$ \\
\hline 16 & $\begin{array}{l}\text { Pekerjaan pembesian di } \\
\text { ketinggian }\end{array}$ & $\begin{array}{l}\text { Pekerja tergores besi atau besi bendrat } \\
\text { Pekerja terjepit mesin bending }\end{array}$ \\
\hline
\end{tabular}




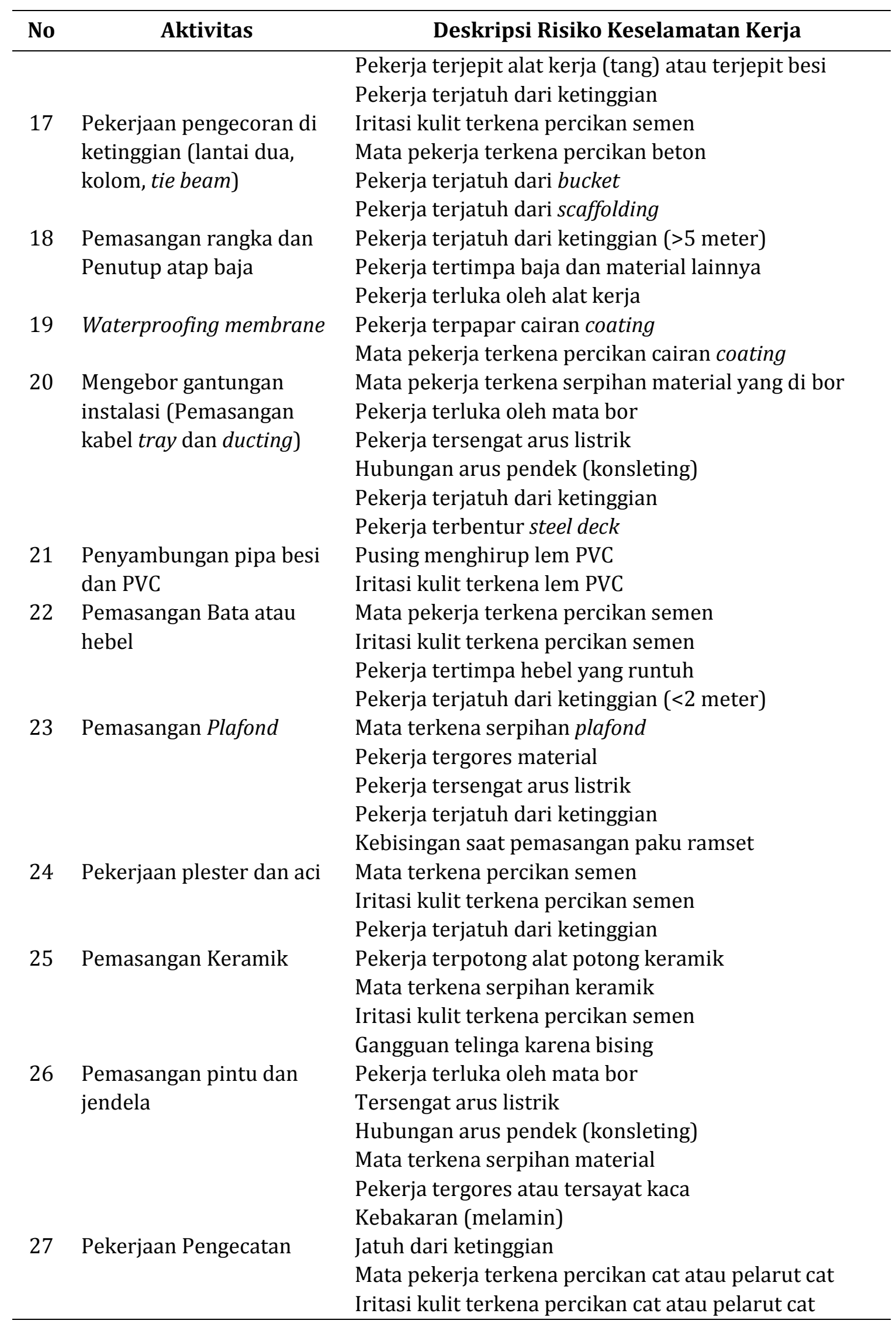


Berdasarkan tabel 1 dapat diketahui bahwa setiap tahap aktivitas pada Proyek Pengembangan Bandara Internasional Juanda Terminal 2 Surabaya memiliki risiko di bidang keselamatan kerja yang dapat menimbulkan kerugian baik pada pekerja maupun pada perusahaan.

\section{Penilaian Risiko}

Hasil penilaian risiko keselamatan kerja berdasarkan tingkat kemungkinan dan keparahan dengan bantuan matriks risiko oleh peneliti kemudian dirangkum seperti yang disajikan pada tabel 2 berikut.

Tabel 2 Hasil Penilaian Risiko Keselamatan Kerja pada Proyek Pembanguan Bandara Juanda Terminal 2 Surabaya Tahun 2013

\begin{tabular}{|c|c|c|c|c|c|}
\hline \multirow{2}{*}{ No } & \multirow{2}{*}{ Aktivitas } & \multirow{2}{*}{$\begin{array}{c}\text { Deskripsi Risiko Keselamatan } \\
\text { Kerja }\end{array}$} & \multicolumn{2}{|c|}{ Risiko } & \multirow{2}{*}{$\begin{array}{l}\text { Indeks } \\
\text { Risiko }\end{array}$} \\
\hline & & & $\mathbf{K M}$ & $\mathbf{K P}$ & \\
\hline \multirow[t]{3}{*}{1} & $\begin{array}{l}\text { Pembersihan } \\
\text { Lokasi }\end{array}$ & $\begin{array}{l}\text { Pekerja tergores atau terpotong } \\
\text { material tajam }\end{array}$ & 5 & 2 & High \\
\hline & & $\begin{array}{l}\text { Pekerja tersandung, jatuh dari } \\
\text { ketinggian yang sama }\end{array}$ & 4 & 2 & Moderate \\
\hline & & Pekerja tergigit ular & 1 & 4 & Moderate \\
\hline \multirow[t]{3}{*}{2} & Mobilisasi dan & Pekerja tertabrak alat berat & 2 & 4 & Moderate \\
\hline & demobilisasi alat & Pekerja terpapar debu & 3 & 2 & Moderate \\
\hline & berat & $\begin{array}{l}\text { Material atau alat lain tertabrak } \\
\text { alat berat }\end{array}$ & 2 & 3 & Moderate \\
\hline \multirow[t]{4}{*}{3} & $\begin{array}{l}\text { Pembongkaran } \\
\text { Bangunan }\end{array}$ & $\begin{array}{l}\text { Pekerja tertimpa bongkaran } \\
\text { bangunan }\end{array}$ & 2 & 4 & Moderate \\
\hline & existing & $\begin{array}{l}\text { Pekerja tergores atau Tersayat } \\
\text { material tajam }\end{array}$ & 4 & 2 & Moderate \\
\hline & & $\begin{array}{l}\text { Mata Pekerja Terkena serpihan } \\
\text { material }\end{array}$ & 4 & 2 & Moderate \\
\hline & & Pekerja tertabrak lengan excavator & 2 & 3 & Moderate \\
\hline \multirow[t]{3}{*}{4} & $\begin{array}{l}\text { Penggalian tanah } \\
\text { dan perapihan }\end{array}$ & $\begin{array}{l}\text { Pekerja terkena pacul atau alat gali } \\
\text { lainnya }\end{array}$ & 3 & 2 & Moderate \\
\hline & dasar galian & Pekerja terpeleset atau terjatuh & 3 & 2 & Moderate \\
\hline & & Pekerja terkena longsoran galian & 1 & 3 & Moderate \\
\hline \multirow[t]{2}{*}{5} & Pasang bongkar & Scaffolding roboh & 4 & 5 & Extreme \\
\hline & scaffolding & $\begin{array}{l}\text { Pekerja jatuh dari ketinggian (di } \\
\text { atas } 2 \text { meter) }\end{array}$ & 4 & 5 & Extreme \\
\hline \multirow[t]{5}{*}{6} & $\begin{array}{l}\text { Pengoperasian } \\
\text { dan angkat }\end{array}$ & $\begin{array}{l}\text { Pekerja tertimpa material yang } \\
\text { diangkat }\end{array}$ & 3 & 5 & High \\
\hline & $\begin{array}{l}\text { angkut material } \\
\text { menggunakan }\end{array}$ & $\begin{array}{l}\text { Pekerja tertabrak material yang } \\
\text { diangkat }\end{array}$ & 2 & 4 & Moderate \\
\hline & Tower Crane & $\begin{array}{l}\text { Kerusakan material yg terjatuh } \\
\text { atau tertimpa }\end{array}$ & 2 & 3 & Moderate \\
\hline & & TowerCrane roboh & 3 & 5 & High \\
\hline & & $\begin{array}{l}\text { Operator terjatuh saat memanjat } \\
\text { tower crane }\end{array}$ & 3 & 4 & High \\
\hline
\end{tabular}




\begin{tabular}{|c|c|c|c|c|c|}
\hline \multirow{2}{*}{ No } & \multirow{2}{*}{ Aktivitas } & \multirow{2}{*}{$\begin{array}{c}\text { Deskripsi Risiko Keselamatan } \\
\text { Kerja }\end{array}$} & \multicolumn{2}{|c|}{ Risiko } & \multirow{2}{*}{$\begin{array}{l}\text { Indeks } \\
\text { Risiko }\end{array}$} \\
\hline & & & KM & $\mathbf{K P}$ & \\
\hline \multirow[t]{8}{*}{7} & $\begin{array}{l}\text { Welding, Cutting } \\
\text { (Hot work) }\end{array}$ & $\begin{array}{l}\text { Mata Pekerja Terkena serpihan } \\
\text { material (gram) }\end{array}$ & 5 & 2 & High \\
\hline & & $\begin{array}{l}\text { Kulit pekerja terkena percikan api } \\
\text { las }\end{array}$ & 4 & 2 & Moderate \\
\hline & & $\begin{array}{l}\text { Iritasi Mata terpapar fume logam } \\
\text { atau asap las }\end{array}$ & 5 & 2 & High \\
\hline & & $\begin{array}{l}\text { Pekerja tersengat arus listrik (las } \\
\text { elektroda) }\end{array}$ & 3 & 5 & High \\
\hline & & Hubungan arus pendek atau & 3 & 5 & High \\
\hline & & Konsleting (kabel power) & & & \\
\hline & & $\begin{array}{l}\text { Pekerja terkena ledakan tabung } \\
\text { LPG (las LPG) }\end{array}$ & 2 & 5 & High \\
\hline & & Kebakaran akibat percikan api & 3 & 4 & High \\
\hline \multirow[t]{2}{*}{8} & $\begin{array}{l}\text { Grinding, } \\
\text { Chipping, Cutting }\end{array}$ & $\begin{array}{l}\text { Mata Pekerja Terkena serpihan } \\
\text { material }\end{array}$ & 5 & 2 & High \\
\hline & & $\begin{array}{l}\text { Pekerja tersayat atau terpotong } \\
\text { alat kerja }\end{array}$ & 5 & 4 & High \\
\hline \multirow[t]{4}{*}{9} & Pemancangan & $\begin{array}{l}\text { Pekerja tertimpa tiang pancang } \\
\text { yang roboh }\end{array}$ & 1 & 4 & Moderate \\
\hline & & Pekerja Tertabrak tiang pancang & 3 & 4 & High \\
\hline & & $\begin{array}{l}\text { Pekerja terluka oleh alat kerja } \\
\text { (linggis pendek dan atau bodem) }\end{array}$ & 4 & 2 & Moderate \\
\hline & & Pekerja tergores logam sambungan & 1 & 2 & Low \\
\hline \multirow[t]{2}{*}{10} & $\begin{array}{l}\text { Pembuatan Lean } \\
\text { concrete }\end{array}$ & $\begin{array}{l}\text { Iritasi kulit terkena percikan } \\
\text { semen }\end{array}$ & 3 & 2 & Moderate \\
\hline & & Terpapar debu & 2 & 2 & Moderate \\
\hline \multirow[t]{3}{*}{11} & $\begin{array}{l}\text { Pekerjaan } \\
\text { bongkar pasang }\end{array}$ & $\begin{array}{l}\text { Pekerja tergores material bekisting } \\
\text { (kayu atau logam) }\end{array}$ & 5 & 2 & High \\
\hline & bekisting & Pekerja tertusuk paku & 5 & 2 & High \\
\hline & & Pekerja terpukul palu & 3 & 2 & Moderate \\
\hline \multirow[t]{4}{*}{12} & Pekerjaan & Pekerja tersayat besi & 5 & 3 & High \\
\hline & pembesian & Pekerja tertusuk besi bendrat & 4 & 2 & Moderate \\
\hline & & Pekerja terjepit mesin bending & 1 & 3 & Moderate \\
\hline & & $\begin{array}{l}\text { Pekerja terjepit alat kerja (tang) } \\
\text { atau terjepit besi }\end{array}$ & 4 & 2 & Moderate \\
\hline \multirow[t]{3}{*}{13} & $\begin{array}{l}\text { Pekerjaan } \\
\text { pengecoran }\end{array}$ & $\begin{array}{l}\text { Iritasi kulit terkena percikan } \\
\text { semen }\end{array}$ & 3 & 2 & Moderate \\
\hline & $\begin{array}{l}\text { (lantai dasar dan } \\
\text { slofe) }\end{array}$ & $\begin{array}{l}\text { Mata pekerja terkena percikan } \\
\text { beton }\end{array}$ & 3 & 3 & High \\
\hline & & Pekerja terpapar getaran vibrator & 4 & 2 & Moderate \\
\hline \multirow[t]{3}{*}{14} & $\begin{array}{l}\text { Pekerjaan } \\
\text { bongkar pasang }\end{array}$ & $\begin{array}{l}\text { Pekerja tergores material bekisting } \\
\text { (kayu atau logam) }\end{array}$ & 5 & 2 & High \\
\hline & bekisting di & Pekerja tertusuk paku & 5 & 2 & High \\
\hline & ketinggian & Pekerja terpukul palu & 4 & 2 & Moderate \\
\hline
\end{tabular}




\begin{tabular}{|c|c|c|c|c|c|}
\hline \multirow{4}{*}{ No } & \multirow{4}{*}{ Aktivitas } & \multirow{2}{*}{$\begin{array}{c}\text { Deskripsi Risiko Keselamatan } \\
\text { Kerja }\end{array}$} & \multicolumn{2}{|c|}{ Risiko } & \multirow{2}{*}{$\begin{array}{l}\text { Indeks } \\
\text { Risiko }\end{array}$} \\
\hline & & & KM & KP & \\
\hline & & Pekerja terjatuh dari ketinggian & 4 & 5 & Extreme \\
\hline & & $\begin{array}{l}\text { Pekerja kekurangan oksigen } \\
\text { (bekisting GWT) }\end{array}$ & 1 & 5 & High \\
\hline \multirow[t]{3}{*}{15} & Pemasangan & Tergores material besi & 3 & 2 & Moderate \\
\hline & steeldeck & Terjepit material besi & 3 & 2 & Moderate \\
\hline & & Tersengat arus listrik & 1 & 5 & High \\
\hline \multirow[t]{4}{*}{16} & $\begin{array}{l}\text { Pekerjaan } \\
\text { pembesian di }\end{array}$ & $\begin{array}{l}\text { Pekerja tergores besi atau besi } \\
\text { bendrat }\end{array}$ & 4 & 2 & Moderate \\
\hline & ketinggian & Pekerja terjepit mesin bending & 1 & 3 & Moderate \\
\hline & & $\begin{array}{l}\text { Pekerja terjepit alat kerja (tang) } \\
\text { atau terjepit besi }\end{array}$ & 3 & 2 & Moderate \\
\hline & & Pekerja terjatuh dari ketinggian & 4 & 5 & Extreme \\
\hline \multirow[t]{4}{*}{17} & $\begin{array}{l}\text { Pekerjaan } \\
\text { pengecoran di }\end{array}$ & $\begin{array}{l}\text { Iritasi kulit terkena percikan } \\
\text { semen }\end{array}$ & 3 & 2 & Moderate \\
\hline & ketinggian & $\begin{array}{l}\text { Mata pekerja terkena percikan } \\
\text { beton }\end{array}$ & 3 & 3 & High \\
\hline & & Pekerja terjatuh dari bucket & 3 & 5 & High \\
\hline & & Pekerja terjatuh dari scaffolding & 4 & 5 & Extreme \\
\hline \multirow[t]{3}{*}{18} & $\begin{array}{l}\text { Pemasangan } \\
\text { rangka \& }\end{array}$ & $\begin{array}{l}\text { Pekerja terjatuh dari ketinggian } \\
\text { ( }>5 \text { meter) }\end{array}$ & 4 & 5 & Extreme \\
\hline & $\begin{array}{l}\text { Penutup atap } \\
\text { baja }\end{array}$ & $\begin{array}{l}\text { Pekerja tertimpa baja dan material } \\
\text { lainnya }\end{array}$ & 4 & 5 & Extreme \\
\hline & & Pekerja terluka oleh alat kerja & 3 & 2 & Moderate \\
\hline \multirow[t]{6}{*}{20} & $\begin{array}{l}\text { Mengebor } \\
\text { gantungan }\end{array}$ & $\begin{array}{l}\text { Mata pekerja terkena serpihan } \\
\text { material yang di bor }\end{array}$ & 3 & 2 & Moderate \\
\hline & instalasi & Pekerja terluka oleh mata bor & 3 & 4 & High \\
\hline & (Pemasangan & Pekerja tersengat arus listrik & 3 & 5 & High \\
\hline & $\begin{array}{l}\text { kabel tray dan } \\
\text { ducting) }\end{array}$ & $\begin{array}{l}\text { Hubungan arus pendek } \\
\text { (konsleting) }\end{array}$ & 3 & 5 & High \\
\hline & & Pekerja terjatuh dari ketinggian & 4 & 5 & Extreme \\
\hline & & Pekerja terbentur steel deck & 2 & 2 & Low \\
\hline \multirow[t]{2}{*}{21} & Penyambungan & Pusing menghirup lem PVC & 3 & 2 & Moderate \\
\hline & pipa besi \& PVC & Iritasi kulit terkena lem PVC & 2 & 2 & Low \\
\hline \multirow[t]{4}{*}{22} & $\begin{array}{l}\text { Pemasangan } \\
\text { Bata atau hebel }\end{array}$ & $\begin{array}{l}\text { Mata pekerja terkena percikan } \\
\text { semen }\end{array}$ & 3 & 3 & High \\
\hline & & $\begin{array}{l}\text { Iritasi kulit terkena percikan } \\
\text { semen }\end{array}$ & 3 & 2 & Moderate \\
\hline & & $\begin{array}{l}\text { Pekerja tertimpa hebel yang } \\
\text { runtuh }\end{array}$ & 1 & 3 & Moderate \\
\hline & & $\begin{array}{l}\text { Pekerja terjatuh dari ketinggian } \\
\text { ( }<2 \text { meter) }\end{array}$ & 3 & 4 & High \\
\hline \multirow[t]{3}{*}{23} & Pemasangan & Mata terkena serpihan plafond & 3 & 2 & Moderate \\
\hline & Plafond & Pekerja tergores material & 3 & 2 & Moderate \\
\hline & & Pekerja tersengat arus listrik & 3 & 5 & High \\
\hline
\end{tabular}




\begin{tabular}{|c|c|c|c|c|c|}
\hline \multirow{4}{*}{ No } & \multirow{4}{*}{ Aktivitas } & \multirow{2}{*}{$\begin{array}{c}\text { Deskripsi Risiko Keselamatan } \\
\text { Kerja }\end{array}$} & \multicolumn{2}{|c|}{ Risiko } & \multirow{2}{*}{$\begin{array}{l}\text { Indeks } \\
\text { Risiko }\end{array}$} \\
\hline & & & $\mathbf{K M}$ & $\mathbf{K P}$ & \\
\hline & & Pekerja terjatuh dari ketinggian & 3 & 4 & High \\
\hline & & $\begin{array}{l}\text { Kebisingan saat pemasangan paku } \\
\text { ramset }\end{array}$ & 2 & 4 & Moderate \\
\hline \multirow[t]{3}{*}{24} & Pekerjaan & Mata terkena percikan semen & 3 & 3 & High \\
\hline & plester dan aci & $\begin{array}{l}\text { Iritasi kulit terkena percikan } \\
\text { semen }\end{array}$ & 3 & 2 & Moderate \\
\hline & & Pekerja terjatuh dari ketinggian & 4 & 4 & High \\
\hline \multirow[t]{4}{*}{25} & $\begin{array}{l}\text { Pemasangan } \\
\text { Keramik }\end{array}$ & $\begin{array}{l}\text { Pekerja terpotong alat potong } \\
\text { keramik }\end{array}$ & 4 & 4 & High \\
\hline & & Mata terkena serpihan keramik & 2 & 2 & Low \\
\hline & & $\begin{array}{l}\text { Iritasi kulit terkena percikan } \\
\text { semen }\end{array}$ & 3 & 2 & Moderate \\
\hline & & Gangguan telinga karena bising & 2 & 4 & Moderate \\
\hline \multirow[t]{6}{*}{26} & Pemasangan & Pekerja terluka oleh mata bor & 3 & 3 & High \\
\hline & pintu dan & Tersengat arus listrik & 3 & 5 & High \\
\hline & jendela & $\begin{array}{l}\text { Hubungan arus pendek } \\
\text { (konsleting) }\end{array}$ & 3 & 5 & High \\
\hline & & Mata terkena serpihan material & 3 & 2 & Moderate \\
\hline & & Pekerja tergores atau tersayat kaca & 3 & 4 & High \\
\hline & & Kebakaran (melamin) & 3 & 4 & High \\
\hline \multirow[t]{3}{*}{27} & Pekerjaan & Jatuh dari ketinggian & 4 & 5 & Extreme \\
\hline & Pengecatan & $\begin{array}{l}\text { Mata pekerja terkena percikan cat } \\
\text { atau pelarut cat }\end{array}$ & 3 & 3 & High \\
\hline & & $\begin{array}{l}\text { Iritasi kulit terkena percikan cat } \\
\text { atau pelarut cat }\end{array}$ & 3 & 2 & Moderate \\
\hline
\end{tabular}

Berdasarkan tabel 2, diketahui terdapat 4 low risk, 48 moderate risk, 39 high risk, dan 9 extreme risk.

\section{Evaluasi (Penyusunan Prioritas) Risiko}

Risiko yang masih dapat ditoleransi oleh perusahaan sesuai AS/NZS 4360 (2004) adalah risiko dengan nilai low sampai dengan moderate ${ }^{3}$, oleh sebab itu risiko yang menjadi fokus dalam penyusunan prioritas adalah risiko dengan nilai indeks risiko High dan Extreme seperti yang terdapat pada tabel 3 .

Tabel 3 Untolerable Risk pada Proyek Pembanguan Bandara Juanda Terminal 2 Surabaya Tahun 2013

\begin{tabular}{cllc}
\hline No & \multicolumn{1}{c}{ Aktivitas } & \multicolumn{1}{c}{$\begin{array}{c}\text { Deskripsi Risiko Keselamatan } \\
\text { Kerja }\end{array}$} & Indeks Risiko \\
\hline 1 & Pembersihan Lokasi & $\begin{array}{l}\text { Pekerja tergores atau terpotong } \\
\text { material tajam }\end{array}$ & High \\
& & $\begin{array}{l}\text { Scaffolding roboh } \\
\text { Pekerja jatuh dari ketinggian (di }\end{array}$ & $\begin{array}{l}\text { Extreme } \\
\text { Extreme }\end{array}$ \\
\hline 2 & Pasang bongkar & scaffolding & Pelation
\end{tabular}




\begin{tabular}{|c|c|c|c|}
\hline No & Aktivitas & $\begin{array}{c}\text { Deskripsi Risiko Keselamatan } \\
\text { Kerja } \\
\end{array}$ & Indeks Risiko \\
\hline & & atas 2 meter) & \\
\hline \multirow[t]{3}{*}{3} & $\begin{array}{l}\text { Pengoperasian dan } \\
\text { angkat angkut material }\end{array}$ & $\begin{array}{l}\text { Pekerja tertimpa material yang } \\
\text { diangkat }\end{array}$ & High \\
\hline & menggunakan Tower & TowerCrane roboh & High \\
\hline & Crane & $\begin{array}{l}\text { Operator terjatuh saat memanjat } \\
\text { tower crane }\end{array}$ & High \\
\hline \multirow[t]{7}{*}{4} & $\begin{array}{l}\text { Welding, Cutting (Hot } \\
\text { work) }\end{array}$ & $\begin{array}{l}\text { Mata Pekerja Terkena serpihan } \\
\text { material (gram) }\end{array}$ & High \\
\hline & & $\begin{array}{l}\text { Iritasi Mata terpapar fume logam } \\
\text { atau asap las }\end{array}$ & High \\
\hline & & $\begin{array}{l}\text { Pekerja tersengat arus listrik (las } \\
\text { elektroda) }\end{array}$ & High \\
\hline & & Hubungan arus pendek atau & High \\
\hline & & Konsleting (kabel power) & \\
\hline & & $\begin{array}{l}\text { Pekerja terkena ledakan tabung } \\
\text { LPG (las LPG) }\end{array}$ & High \\
\hline & & Kebakaran akibat percikan api & High \\
\hline \multirow[t]{2}{*}{5} & $\begin{array}{l}\text { Grinding, Chipping, } \\
\text { Cutting }\end{array}$ & $\begin{array}{l}\text { Mata Pekerja Terkena serpihan } \\
\text { material }\end{array}$ & High \\
\hline & & $\begin{array}{l}\text { Pekerja tersayat atau terpotong } \\
\text { alat kerja }\end{array}$ & High \\
\hline 6 & Pemancangan & Pekerja Tertabrak tiang pancang & High \\
\hline \multirow[t]{2}{*}{7} & $\begin{array}{l}\text { Pekerjaan pemasangan } \\
\text { dan pembongkaran }\end{array}$ & $\begin{array}{l}\text { Pekerja tergores material bekisting } \\
\text { (kayu/logam) }\end{array}$ & High \\
\hline & bekisting & Pekerja tertusuk paku & High \\
\hline 8 & Pekerjaan pembesian & Pekerja tersayat besi & High \\
\hline 9 & $\begin{array}{l}\text { Pekerjaan pengecoran } \\
\text { (lantai dasar dan slofe) }\end{array}$ & $\begin{array}{l}\text { Mata pekerja terkena percikan } \\
\text { beton }\end{array}$ & High \\
\hline \multirow[t]{4}{*}{10} & $\begin{array}{l}\text { Pekerjaan pemasangan } \\
\text { dan pembongkaran }\end{array}$ & $\begin{array}{l}\text { Pekerja tergores material bekisting } \\
\text { (kayu/logam) }\end{array}$ & High \\
\hline & bekisting di ketinggian & Pekerja tertusuk paku & High \\
\hline & & Pekerja terjatuh dari ketinggian & Extreme \\
\hline & & $\begin{array}{l}\text { Pekerja kekurangan oksigen } \\
\text { (bekisting GWT) }\end{array}$ & High \\
\hline 11 & Pemasangan steeldeck & Tersengat arus listrik & High \\
\hline 12 & $\begin{array}{l}\text { Pekerjaan pembesian } \\
\text { di ketinggian }\end{array}$ & Pekerja terjatuh dari ketinggian & Extreme \\
\hline \multirow[t]{3}{*}{13} & $\begin{array}{l}\text { Pekerjaan pengecoran } \\
\text { di ketinggian (lantai }\end{array}$ & $\begin{array}{l}\text { Mata pekerja terkena percikan } \\
\text { beton }\end{array}$ & High \\
\hline & dua, kolom, tie beam) & Pekerja terjatuh dari bucket & High \\
\hline & & Pekerja terjatuh dari scaffolding & Extreme \\
\hline \multirow[t]{2}{*}{14} & $\begin{array}{l}\text { Pemasangan rangka } \\
\text { dan Penutup atap baja }\end{array}$ & $\begin{array}{l}\text { Pekerja terjatuh dari ketinggian } \\
(>5 \text { meter })\end{array}$ & Extreme \\
\hline & & Pekerja tertimpa baja dan material & Extreme \\
\hline
\end{tabular}




\begin{tabular}{|c|c|c|c|}
\hline No & Aktivitas & $\begin{array}{c}\text { Deskripsi Risiko Keselamatan } \\
\text { Kerja }\end{array}$ & Indeks Risiko \\
\hline & & lainnya & \\
\hline \multirow[t]{4}{*}{15} & Mengebor gantungan & Pekerja terluka oleh mata bor & High \\
\hline & instalasi (Pemasangan & Pekerja tersengat arus listrik & High \\
\hline & kabel tray dan ducting) & $\begin{array}{l}\text { Hubungan arus pendek } \\
\text { (konsleting) }\end{array}$ & High \\
\hline & & Pekerja terjatuh dari ketinggian & Extreme \\
\hline \multirow[t]{2}{*}{16} & $\begin{array}{l}\text { Pemasangan Bata atau } \\
\text { hebel }\end{array}$ & $\begin{array}{l}\text { Mata pekerja terkena percikan } \\
\text { semen }\end{array}$ & High \\
\hline & & Pekerja terjatuh dari ketinggian & High \\
\hline \multirow[t]{2}{*}{17} & Pemasangan Plafond & Pekerja tersengat arus listrik & High \\
\hline & & Pekerja terjatuh dari ketinggian & High \\
\hline \multirow[t]{2}{*}{18} & Pekerjaan plester dan & Mata terkena percikan semen & High \\
\hline & aci & Pekerja terjatuh dari ketinggian & High \\
\hline 19 & Pemasangan Keramik & $\begin{array}{l}\text { Pekerja terpotong alat potong } \\
\text { keramik }\end{array}$ & High \\
\hline \multirow[t]{5}{*}{20} & Pemasangan pintu dan & Pekerja terluka oleh mata bor & High \\
\hline & jendela & Tersengat arus listrik & High \\
\hline & & $\begin{array}{l}\text { Hubungan arus pendek } \\
\text { (konsleting) }\end{array}$ & High \\
\hline & & Pekerja tergores atau tersayat kaca & High \\
\hline & & Kebakaran (melamin) & High \\
\hline 20 & Pekerjaan Pengecatan & $\begin{array}{l}\text { Pekerja terjatuh dari ketinggian } \\
\text { Mata pekerja terkena percikan cat } \\
\text { atau pelarut cat }\end{array}$ & $\begin{array}{l}\text { Extreme } \\
\text { High }\end{array}$ \\
\hline
\end{tabular}

Pada tabel 3 diketahui bahwa terdapat beberapa deskripsi insiden yang serupa atau sejenis, maka untuk memudahkan proses penyusunan prioritas risiko, peneliti menggolongkan risiko keselamatan kerja yang tidak dapat ditoleransi berdasarkan diskripsi risiko seperti yang dapat dilihat pada tabel 4 .

Tabel 4 Penggolongan dan Pemberian Kode Untolerable Risk berdasarkan Aktivitas Kerja pada Proyek Terminal 2 Tahun 2013

\begin{tabular}{ccll}
\hline No & Kode & \multicolumn{1}{c}{ Deskripsi Risiko } & \multicolumn{1}{c}{ Aktivitas } \\
\hline 1 & A & Pekerja tergores atau & Pembersihan Lokasi \\
& & tersayat atau terpotong & Grinding, Chipping, Cutting \\
& material tajam & Pekerjaan bongkar pasang bekisting \\
& & Pekerjaan pembesian \\
& & & Pemasangan pintu dan jendela \\
\hline 2 & B & Pekerja Terluka oleh alat & Pekerjaan bongkar pasang bekisting \\
& & kerja & (tertusuk paku) \\
& & Mengebor gantungan instalasi \\
& & (Pemasangan kabel tray dan ducting) \\
& & Pemasangan Keramik (alat potong \\
& & keramik)
\end{tabular}




\begin{tabular}{|c|c|c|c|}
\hline No & Kode & Deskripsi Risiko & Aktivitas \\
\hline & & & Pemasangan pintu dan jendela (alat bor) \\
\hline \multirow[t]{14}{*}{3} & $\mathrm{C}$ & Pekerja jatuh dari & Pasang bongkar scaffolding \\
\hline & & ketinggian & Pekerjaan bongkar pasang bekisting di \\
\hline & & & ketinggian \\
\hline & & & Pekerjaan pembesian di ketinggian \\
\hline & & & Pekerjaan pengecoran di ketinggian (lantai \\
\hline & & & dua, kolom, tie beam) \\
\hline & & & Pemasangan rangka dan Penutup atap baja \\
\hline & & & Mengebor gantungan instalasi \\
\hline & & & (Pemasangan kabel tray dan ducting) \\
\hline & & & Mengebor gantungan instalasi \\
\hline & & & (Pemasangan kabel tray dan ducting) \\
\hline & & & Pemasangan Bata atau hebel \\
\hline & & & Pekerjaan plester dan aci \\
\hline & & & Pekerjaan Pengecatan \\
\hline \multirow[t]{4}{*}{4} & $\mathrm{D}$ & Pekerja terkena sengatan & Welding, Cutting (Hot work) \\
\hline & & arus listrik & Pemasangan steeldeck \\
\hline & & & Pemasangan Bata atau hebel \\
\hline & & & Pemasangan pintu dan jendela \\
\hline \multirow[t]{4}{*}{5} & E & Hubungan arus pendek & Welding, Cutting (Hot work) \\
\hline & & (Konsleting) & Mengebor gantungan instalasi \\
\hline & & & (Pemasangan kabel tray dan ducting) \\
\hline & & & Pemasangan pintu dan jendela \\
\hline \multirow[t]{9}{*}{6} & $\mathrm{~F}$ & Mata pekerja terkena & Welding, Cutting (Hot work) \\
\hline & & percikan atau serpihan & Grinding, Chipping, Cutting \\
\hline & & material & Pekerjaan pengecoran (lantai dasar dan \\
\hline & & & slofe) \\
\hline & & & Pekerjaan pengecoran di ketinggian (lantai \\
\hline & & & dua, kolom, tie beam) \\
\hline & & & Pemasangan Bata atau hebel \\
\hline & & & Pekerjaan plester dan aci \\
\hline & & & Pekerjaan Pengecatan \\
\hline \multirow[t]{2}{*}{7} & G & Kebakaran atau Ledakan & Welding, Cutting (Hot work) \\
\hline & & & Pemasangan pintu dan jendela \\
\hline \multirow[t]{2}{*}{8} & $\mathrm{H}$ & $\begin{array}{l}\text { Pekerja tertimpa material } \\
\text { yang diangkat }\end{array}$ & $\begin{array}{l}\text { Pengoperasian dan angkat angkut material } \\
\text { menggunakan } T C\end{array}$ \\
\hline & & & Pemasangan rangka dan Penutup atap baja \\
\hline 9 & $\mathrm{I}$ & Perancah roboh & Pasang bongkar scaffolding \\
\hline 10 & $\mathrm{~J}$ & $T C$ roboh & $\begin{array}{l}\text { Pengoperasian dan angkat angkut material } \\
\text { menggunakan } T C\end{array}$ \\
\hline 11 & $\mathrm{~K}$ & $\begin{array}{l}\text { Operator terjatuh saat } \\
\text { memanjat } T C\end{array}$ & $\begin{array}{l}\text { Pengoperasian dan angkat angkut material } \\
\text { menggunakan } T C\end{array}$ \\
\hline 12 & $\mathrm{~L}$ & $\begin{array}{l}\text { Pekerja Tertabrak tiang } \\
\text { pancang }\end{array}$ & Pemancangan \\
\hline
\end{tabular}




\begin{tabular}{ccll}
\hline No & Kode & \multicolumn{1}{c}{ Deskripsi Risiko } & \multicolumn{1}{c}{ Aktivitas } \\
\hline 13 & M & $\begin{array}{l}\text { Pekerja kekurangan } \\
\text { oksigen }\end{array}$ & $\begin{array}{l}\text { Pekerjaan bongkar pasang bekisting di } \\
\text { ketinggian (bekisting GWT) }\end{array}$ \\
\hline
\end{tabular}

Berdasarkan Hasil akhir $Q$ sort Technique, lima prioritas risiko keselamatan kerja di Proyek Terminal 2 antara lain: pekerja terjatuh dari ketinggian; pekerja tersengat aliran listrik; pekerja tertimpa material yang diangkat; kebakaran atau ledakan; dan perancah roboh.

\section{Akar Masalah}

Akar masalah risiko keselamatan kerja dibagi menjadi dua yakni teknis dan non-teknis.Akar masalah teknis berhubungan dengan faktor mesin atau alat, material, dan lingkungan sedangkan faktor non-teknis berhubungan dengan faktor manusia. Berdasarkan root cause analysis yang telah dilakukan, diketahui bahwa faktor manusia adalah penyebab dasar kecelakaan di Proyek Terminal 2, yang meliputi: berlakunya jam lembur, pekerja kurang pengalaman dan kurangnya pemahaman terhadap prosedur kerja, dan kurangnya kesadaran pekerja akan pentingnya penerapan K3 di tempat kerja.

1. Lembur

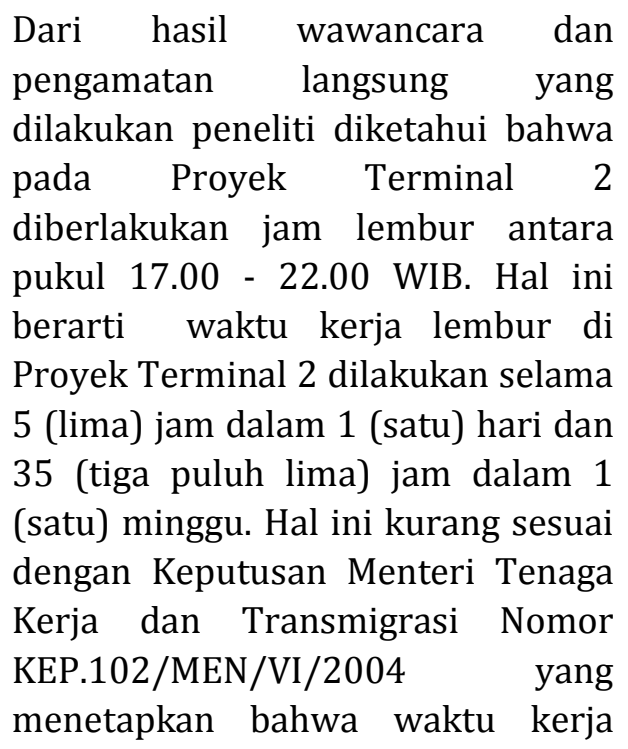

lembur hanya dapat dilakukan paling banyak 3 (tiga) jam dalam 1 (satu) hari dan 14 (empat belas) jam dalam 1 (satu) minggu4.

Jam kerja (lembur) yang berlebihan dapat menyebabkan pekerja yang bersangkutan mengalami kelelahan. Peneliti tidak melakukan pengukuran terhadap kelelahan kerja yang dialami oleh pekerja, akan tetapi berdasarkan keterangan yang diberikan pihak K3LMP melalui wawancara menyebutkan bahwa kemungkinan besar pekerja mengalami kelelahan akibat adanya lembur sehingga hal ini memicu terjadinya kecelakaan.

Sejalan dengan penelitian yang dilakukan Rantung (2009) pada keryawan Laboratorium Klinik Prodia Cabang Manado menunjukkan bahwa terdapat hubungan yang signifikan antara lama kerja dengan kelelahan kerja ${ }^{5}$. Lebih lanjut Budiono (2003) menyebutkan bahwa kelelahan kerja dapat berakibat menurunnya perhatian, perlambatan dan hambatan persepsi, lambat dan susah berfikir, penurunan kemauan atau dorongan untuk bekerja, menurunnya efisiensi, kegiatan fisik, dan mental sehingga berujung pada menurunnya produktivitas kerja dan kecelakaan ${ }^{6}$.

Dalam kaitannya dengan kejadian kecelakaan, menurut kajian dokumentasi yang dilakukan peneliti terhadap data kecelakaan pada Proyek Terminal 2, diketahui bahwa kecelakan fatal yang dialami oleh pekerja hingga membutuhkan 
pertolongan medis (dirujuk ke rumah sakit) yakni berupa jatuh dari ketinggian memang banyak dialami pada saat jam lembur.Hal ini mengindikasikan adanya hubungan antara kelelahan kerja dengan kejadian kecelakaan. Sejalan dengan hal tersebut, penelitian mengenai pengaruh jam kerja yang panjang dan penjadwalan kerja terhadap terjadinya kecelakaan kerja pada pekerja konstruksi di Amerika Serikat menyatakan bahwa pekerja yang lembur (bekerja lebih dari 8 jam per hari dan 40 jam per minggu) memiliki tingkat cedera yang lebih tinggi daripada mereka yang bekerja kurang dari 8 jam per hari. Tingkat cedera terus meningkat seiring dengan meningkatnya jam lembur ${ }^{7}$.

Dilihat dari waktu kejadian kecelakaan, fenomena kecelakaan kerja pada Proyek Terminal 2 dimana mayoritas (yakni 66,6\% dari kejadian kecelakaan yang diketahui waktu kejadiannya) terjadi pada rentang waktu pukul 12.00 - 22.00 WIB (jam lembur). Berdasarkan observasi dan analisa peneliti,kecelakaan pada Proyek Terminal 2 yang banyak terjadi pada jam lembur juga dipengaruhi oleh faktor pencahayaan yang tidak adekuat dalam menunjang pekerjaan.

Mengingat kelelahan yang dialami pekerja berhubungan dengan kelebihan jam kerja, maka untuk mengatasi hal ini perlu adanya pengendalian administratif berupa pengaturan ulang jam kerja dan penyediaan asupan kalori yang cukup bagi pekerja.

2. Pekerja Baru Kurang Berpengalaman dan Pemahaman terhadap Prosedur Kerja
Berdasarkan hasil wawancara dan observasi peneliti, diketahui bahwa tidak semua pekerja harian pada Proyek Terminal 2 memiliki pengalaman kerja dan pemahaman mengenai tata cara bekerja yang memadai di bidang konstruksi. Sebagian pekerja yang dipekerjakan merupakan pekerja baru yang minim pengalaman dan pemahaman. Dari hasil wawancara diketahui bahwa hal ini terjadi akibat sistem perekrutan pekerja harian di Proyek Terminal 2 yang dilakukan melalui mandor tanpa persyaratan khusus, sehingga kemungkinan adanya pekerja harian yang kurang pengalaman dan pemahaman mengenai tata cara kerja di bidang konstruksi masih sangat besar. Selain kurangnya pengalaman, kurangnya pemahaman mengenai tata cara kerja di bidang konstruksi, berdasarkan hasil wawancara dan observasi juga disebabkan oleh kurangnya sosialisasi tentang prosedur kerja (IK). Prosedur kerja dalam bentuk instruksi kerja (IK) pada Proyek Terminal 2 hanya disosialisasikan di awal berjalannya proyek tanpa ada penyegaran atau sosialisasi ulang.

Pengalaman kerja merupakan faktor yang dapat mempengaruhi terjadinya kecelakaan akibat kerja. Uraian ini sejalan dengan berbagai hasil penelitian yang menunjukkan bahwa meningginya pengalaman dan keterampilan akan disertai dengan penurunan angka kecelakaan akibat kerja. Kewaspadaan terhadap kecelakaan akibat kerja bertambah baik sejalan dengan pertambahan usiadan lamanya kerja di tempat kerja yang bersangkutan ${ }^{8}$. 
Sama hal nya dengan pengalaman, kurangnya pemahaman terhadap prosedur kerja juga dapat menjadi pemicu terjadinya kecelakaan kerja mengingat prosedur kerja berisi mengenai perincian langkah dari serangkaian fungsi termasuk aspek keselamatan yang diarahkan untuk mencapai hasil yang dikehendaki serta mencegah terjadinya kecelakaan kerja9.

Upaya yang dapat dilakukan untuk mengatasi kurangnya pengalaman dan kurangnya pemahaman terhadap prosedur kerja dapat dilakukan pada tahap input dan proses. Mitigasi yang dilakukan dalam tahap input dapat dilakukan dengan cara memperbaiki sistem perekrutan pekerja misalnya dengan mensyaratkan lama kerja (pengalaman) bekerja di bidang konstruksi dalam jangka waktu tertentu, sedangkan mitigasi pada tahap proses dapat dilakukan dengan mengadakan sosialisasi mengenai IK kepada pekerja. Sosialisasi mengenai IK ini dapat dilakukan secara langsung melalui pertemuan seperti safety talk atau menggunakan media seperti papan pengumuman. Upaya lain yang dapat dilakukan pada tahap proses adalah dengan meningkatkan (optimalisasi) pengawasan terhadap pekerja yang kurang pengalaman dan pemahaman sehingga kesalahan yang kemungkinan dilakukan oleh pekerja yang bersangkutan dapat diatasi sedini mungkin sehingga tidak sampai menimbulkan kecelakaan kerja.

3. Kurangnya Kesadaran Pekerja akan Pentingnya Penerapan K3

Berdasarkan observasi dan wawancara dengan pihak K3LMP, diketahui bahwa masih banyak pekerja yang melakukan pelanggaran terhadap aturan dan prosedur kerja yang berlaku dimana pelanggaran tersebut dapat membahayakan keselamatan mereka. Sejalan dengan hal ini, menurut Intitution of Occupational Safety and Health (2010), sebanyak 73\% kecelakaan kerja dikarenakan oleh perilaku yang tidak aman, dan salah satu perilaku yang tidak aman adalah tidak mengikuti standar prosedur kerja ${ }^{10}$. Pelanggaran yang dilakukan pekerja terhadap aturan dan prosedur kerja yang berlaku menurut hasil wawancara dengan K3LMP diketahui dapat terjadi akibat kurangnya kesadaran akan pentingnya penerapan $\mathrm{K} 3$ di tempat kerja. Ini sejalan dengan hasil penelitian yang dilakukan oleh Masia (2011) yang menyatakan bahwa pelanggaran terhadap aturan keselamatan sebagai akibat rendahnya tingkat kesadaran keselamatan pekerja dapat meningkatkan jumlah insiden atau kecelakaan kerja ${ }^{11}$.

Upaya pengendalian yang dapat direkomendasikan untuk mengatasi kurangnya kesadaran pekerja akan pentingnya penerapan $\mathrm{K} 3$ adalah dengan menerapkan reward and punishment systemdengan harapan mampu memunculkan kesadaran dalam diri para staf pekerja bahwa asset penting dari perusahaan ialah diri pekerja itu sendiri .

\section{Pengendalian Risiko pada Tingkat Unit Kegiatan atau Proyek}

1. ReduceLikelihood or Severity

ReduceLikelihood or Severity merupakan pendekatan yang dirasa paling relevan untuk dilakukan dimana pendekatan ini dilakukan dengan cara menekan kemungkinan 
atau keparahan suatu insiden. Hal ini sejalan dengan yang diungkapkan Ramli (2010)dimana pengendalian risiko pada level unit kegiatan atau proyek lebih bersifat teknis dan langsung di tempat kerja masingmasing11.Proses pengelolaan risiko dilakukan secara rinci untuk setiap aktivitas, proses, lokasi kerja, atau peralatan. Proses pengendalian risiko pada level proyek lebih bersifat teknis dan dikembangkan sesuai dengan kondisi operasi yang ada dalam unit kerja atau proyek dan bersentuhan langsung pada sumber bahaya. Pengendalian risiko dengan cara ini dapat diwujudkan melalui beberapa pendekatan salah satunya seperti yang dikembangkan oleh OHSAS 18001, yakni: eliminasi, substitusi, pengendalian teknis (engineering control), pengendalian administratif, dan penggunaan APD $^{13}$.

\section{Risk Transfer}

Sangat disadari bahwa risiko K3 di bidang apapun terlebih di bidang konstruksi tidak bisa sama sekali dihilangkan, sehingga dalam rangka meringankan beban risiko yang ditanggung oleh pihak kontraktor, pegendalian risiko dengan jalan pengalihan (risk transfer) masih tetap dipandang perlu untuk dilakukan. Berdasarkan wawancara dan observasi yang dilakukan peneliti, pihak kontraktor proyek terminal 2 telah melakukan langkah pengendalian ini dengan mengikutsertakan seluruh pekerja harian dalam asuransi. Hal ini sesuai dengan Peraturan Pemerintah RI Nomor 14 tahun 1993 tentang Penyelenggaraan Program Jaminan Sosial Tenaga Kerja, dimana dalam peraturan tersebut telah ditegaskan bahwa Pengusaha yang mempekerjakan tenaga kerja sebanyak 10 (sepuluh) orang atau lebih wajib mengikut sertakan tenaga kerjanya dalam program jaminan sosial tenaga kerja ${ }^{14}$.

\section{SIMPULAN DAN SARAN}

Merujuk pada hasil identifikasi bahaya dan risiko melalui observasi, kajian dokumentasi, dan brainstorming technique diketahui pada Proyek Pengembangan Bandara Internasional Juanda Terminal 2 Surabaya terdapat 100 risiko yang dapat mengancam keselamatan pekerja. Hasil penilaian risiko menunjukkan $4 \%$ risiko berkategori low, 48\%risiko berkategori moderate, 39\%risiko berkategori high, dan $9 \%$ risiko berkategori extreme. Hasil $Q$ sort technique terhadap high and extreme risk diperoleh 5 prioritas masalah keselamatan kerja yakni: pekerja jatuh dari ketinggian, pekerja tersengat aliran listrik, pekerja tertimpa material yang diangkat, kebakaran atau ledakan, dan perancah (scaffold) roboh. Berdasarkan root cause analysis terhadap masalah keselamatan kerja yang menjadi prioritas, diketahui bahwa penyebab dasar yang dominan adalah dari faktor manusia yakni: kelelahan kerja akibat lembur, pekerja kurang pengalaman dan kurang pemahaman terhadap prosedur kerja, serta kurangnya kesadaran pekerja akan pentingnya penerapan K3 di tempat kerja.

Mengingat kemungkinan besar akar masalah atau penyebab dasar yang dominan adalah dari faktor manusia, maka peneliti merekomendasikan adanya:

1) Pengaturan jam kerja dan tambahan asupan kalori sebagai upaya mitigasi dari kelelahan kerja akibat penerapan jam lembur. 2) Perbaikan sistem perekrutan 
pekerja harian, sosialisasi IK dan peningkatan pengawasan sebagai upaya mitigasi dari masalah kurangnya pengalaman dan pemahaman pekerja terhadap prosedur kerja. 3) Penerapan Reward and Punishment sebagai upaya mitigasi dari masalah kurangnya kesadaran pekerja akan pentingnya penerapan K3.

\section{DAFTAR RUJUKAN}

1] Jamsostek. 2012. Data Kasus Kecelakaan Kerja. http://Jamsostek.go.id(Sitasi 8 Februari 2013)

2] Ramli Soehatman., (2010). Pedoman Praktis Manajemen Risiko dalam Prespektif K3 OHS Risk Management.Jakarta: Dian Rakyat

3] AS/NZS 4360. 2004. 3rd Edition The Australian And New Zealand Standard on Risk Management. NSW Australia: Broadleaf Capital International Pty Ltd

4] Keputusan Menteri Tenaga Kerja dan Transmigrasi Republik Indonesia. 2004. Tentang Waktu Kerja Lembur dan Upah Kerja Lembur

5] Rantung N.A.2009. Hubungan Antara Lama Kerja, Shift Kerja, dan Status Gizi dengan Kelelahan Kerja Karyawan Laboratorium Klinik : Kajian pada Karyawan Laboratorium Klinik Prodia Cabang Manado, tesis, Ilmu Kesehatan Kerja-UGM

6] Budiono Sugeng., dkk.2003. Bunga Rampai Hiperkes \& KK.Semarang: Badan Penerbit UNDIP

7] Australian Safety and Compensation Council. 2006. Work Related Fatigue Summary of Recent Indicative Research. Australia: Australian Government
8] Suma'mur. 2009. Higiene Perusahaan dan Kesehatan Kerja. Gunung Agung, Jakarta

9] Suratno/Konsep Prosedur Kerja. http://sulut.kemenag.go.id/file/fil e/kepegawaian/bnot1341291140. pdf. (Sitasi 8 Februari 2013)

10] IOSH. 2010. Materi Pelajaran Keselamatan dan Kesehatan Kerja Tenaga Kerja Asing - Bidang Konstruksi. Jakarta: Kementrian Tenaga Kerja dan Transmigrasi

11] Masia Uanda. 2011. Unravelling safety compliance in the mining industry: examining the role of work stress, job insecurity, satisfaction and commitment as antecedents. SA Journal of Industrial Psychology.Vol. 37, No. 1. 2011

12] Heliaputra. 2007. Studi Penerapan Manajemen Keselamatan dan Kesehatan Kerja Pada Gudang Penyimpanan Bahan Baku Kimia Industri Pupuk, tesis. Industrial Engineering and Management-ITB

13] OSHAS 18001. 2007. Occupational Health and aSafety Management System - Requirement.

14] Peraturan Pemerintah Republik Indonesia, 1993. Tentang Penyelenggaraan Program Jaminan Sosial Tenaga Kerja 